Kong. Res. J. 3(1) : 49-52, 2016

ISSN 2349-2694

Kongunadu Arts and Science College, Coimbatore.

\title{
ANTIMICROBIAL ACTIVITY OF THE FOLKLORE MEDICINAL PLANT, ACACIA CAESIA (L.) WILD.
}

\author{
Thambiraj, $\mathbf{J}^{\mathbf{1}}$. and S. Paulsamy ${ }^{2 *}$ \\ ${ }^{1} \mathrm{PG}$ and Research Department of Botany, The Madura College (Autonomous), Madurai. \\ ${ }^{2} \mathrm{PG}$ and Research Department of Botany, Kongunadu Arts and Science College, Coimbatore. \\ *E.mail: paulsami@yahoo.com
}

\begin{abstract}
The aim of this study is to evaluate the antimicrobial efficacy of stem bark extracts of the folklore plant species, Acacia caesia L. by using three alcoholic solvents viz; petroleum ether, ethyl acetate and methanol were tested against ten human pathogenic bacteria viz., Pseudomonas aeruginosa, P. stutzeri, Escherichia coli, Micrococcus sp., Lactobacillus sp., Servatia sp., Moraxetta sp., Bacillus subtilis, B. thuriengensis, and Klebsiella pneumoniae and ten human pathogenic fungi viz., Aspergillus niger, A. flavus, A.baumannii, Fusarium oxysporum, F. solani, Mucor rouxii, Alternaria alternata, Candida albicans, Cladosporium sp. and Rhizopus sp. for assessing the antimicrobial properties by adapting disc diffusion method. The results of the study revealed that all extracts showed varied degree of antimicrobial activity against the tested pathogens. However, the ethyl acetate extracts exhibited higher inhibition zone $(17.23 \mathrm{~mm})$ against the bacterium, Klebsiella pneumoniae and the fungus, Mucor rouxii $(30.77 \mathrm{~mm})$. These results support the therapeutic importance of the species, Acacia caesia in curing infectious diseases and encourage the extensive use of this species in health care practices.
\end{abstract}

Keyword: Folklore Medicinal plant, Acacia caesia, Antimicrobial activity.

\section{INTRODUCTION}

Plants have been an essential part of human society since the start of civilization. Around 250 drugs have been identified from plants during Rig veda and Atharvana veda descriptions of the veda period. The rural population in different part of the world is more disposed to traditional ways of treatment because of easy availability and cheaper cost. It is estimated that $80 \%$ of the population is consulting with traditional healers (Iris et al., 2007). The universal role of plants in the treatment of diseases is established by their employment in all important systems of medicine. There are many herbs on earth which lies unexplored in the field of medicine or Science. Many of the plants used today were known to the people of ancient culture throughout the world for their preservative and medicinal powers (Zaika, 1975). However several plants are used in India in the form of crude extracts. Infusions or plaster to treat common infections without scientific evidence of efficacy (Ahmad et al., 1998). Among them, many species of Acacia are found to have diverse photochemical compounds of medicinal properties (Lee et al., 2000; Readel et al., 2001; Seo et al., 2002; Sathishkumar et al., 2009). Acacia caesia L. belongs to the family, Mimosaceae is one such folklore plant used in traditional system of medicine in Coimbatore district of Tamil Nadu, India. It is an armed woody shrub occurring throughout the tropical and sub-tropical regions of India
(Krishnamurthy, 1993). This plant species has been used as a folk remedy for the treatment of skin diseases, asthma, bronchitis, scabies, cold, menstrual disorders and antiseptic also. The leaves of this plant are used as vegetable and the powdered bark and pod are used as substitute for soap and their decoctions as lice killer (Thammanna and Narayana, 1990). Woody branches of this species are used as tooth brushes by tribal folk and the shrub is used as fuel wood. However, no published works are available for the antimicrobial property of stem bark of this plant. Hence in the present study, an attempt has been made to focus the plant in this angle and hence to assess its therapeutic potency.

\section{MATERIALS AND METHODS}

\subsection{Plant material}

Fresh stem parts were collected from the population of $A$. caesia present in the Maruthamalai Hills of Coimbatore District and washed under running tap water, air dried and then homogenized to fine powder and stored in air tight bottles.

\subsection{Preparation of extracts}

$250 \mathrm{~g}$ air-dried stem bark powder was subjected to $250 \mathrm{ml}$ of methanol in soxhlet extraction for 8 hours $\left(50-85^{\circ} \mathrm{C}\right)$. The extracts were concentrated to dryness in a flask evaporator under reduced pressure and controlled temperature $\left(50-60^{\circ} \mathrm{C}\right)$ to yield crude residue, which was then 
stored in refrigerator. To obtain petroleum ether and ethyl acetate extracts, the same method as used to obtain methanol extract was adopted.

\subsection{Media used}

Freshly prepared nutrient agar medium and PDA medium were used for the culture of bacteria and fungi respectively.

\subsection{Microorganisms}

In vitro antimicrobial activity was examined for the chemical extracts of stem bark of the study plant, against ten bacterial species which include the gram positive strains viz., Micrococcus sp., Lactobacillus sp., Bacillus subtilis, B. thuriengensis and gram negative strains viz., Pseudomonas aeruginosa, P. stutzeri, Escherichia coli, Klebsiella pneumoniae, Servatia sp. and Moraxetta sp. and fungal species viz., Aspergillus niger, A. flavus, A. baumannii, Fusarium oxysporum, F. solani, Mucor rouxii, Alternaria alternata, Candida albicans, Cladosporium sp. and Rhizopus sp. All these microorganisms were obtained from the Department of Microbiology, Tamil Nadu Agricultural University, Coimbatore. All the microorganisms were maintained at $4^{\circ} \mathrm{C}$ on nutrient agar slants (for bacteria) and PDA slants (for fungi) until furtheruse.

\subsection{Antimicrobial assay}

The alcoholic extracts were tested for their effect against the growth of pathogenic bacteria and fungi by disc diffusion method (Bauer et al., 1966). Both the organisms, bacteria and fungi tested were inoculated into nutrient agar and PDA media respectively. After an incubation period of $24 \mathrm{hrs}$ at a temperature of $35^{\circ} \mathrm{C}$, three or four colonies isolated from these media were inoculated into $4 \mathrm{ml}$ of nutrient broth and incubated for $2 \mathrm{hrs}$ at $35^{\circ} \mathrm{C}$. The cultures were adjusted with sterile saline solution to obtain turbidity. Petri dishes containing MullerHinton agar medium and PDA medium were streaked with these microbial suspensions of bacteria and fungi respectively. Disks of $6 \mathrm{~mm}$ diameter were impregnated with the extracts of petroleum ether, methanol and ethyl acetate separately. Tetracycline is used as positive control. After equilibrium at $4^{\circ} \mathrm{C}$, the plates were incubated overnight at $37^{\circ} \mathrm{C}$ and the diameter of any resulting zones of inhibition was measured. Each experiment was repeated at least three times.

\section{RESULTS AND DISCUSSION}

The antibacterial activity of the all the alcoholic stem bark extracts of the study species, Acacia caesia generally showed inhibitory activity against the growth of Bacillus subtilis, Bacillus thuringiensis, Klebsiella pneumoniae and Moraxetta sp., However, towards Micrococcus sp., Lactobacillus sp., Escherichia coli, Pseudomonas aeruginosa, P. stutzeri and Serratia sp., and all these extracts showed activity with less pronounced manner (Table 1). It is explained that the different phytochemicals like steroids, cardiac glycosides, anthraquinone, flavonoids and phenolics extracted by different solvents may be responsible for their antibacterial effects (Tambekar and Khante, 2010). Further, the ethyl acetate extract has determined to have highest inhibitory activity $(17.23 \mathrm{~mm}$ diameter inhibitory zone) against the bacterium, Klebsiella pneumoniae (gram negative) and (16.93 $\mathrm{mm}$ diameter inhibitory zone) against the bacterium, Pseudomonas stutzeri followed by the methanol extract against the bacterium, Bacillus thuringiensis, (gram positive) (16.63 $\mathrm{mm}$ diameter inhibitory zone). It indicates the presence of effective active principle compounds in the ethyl acetate and methanol extracts of stem bark part of A. caesia to suppress both gram negative and gram positive bacteria. It has been observed further that the ethyl acetate extracts showed significantly higher inhibitory activity against the colonial growth of Bacillus subtilis, B. thuringiensis, Escherichia coli, Pseudomonas aeruginosa and Serratia sp. than that of the commercially available antibiotic, tetracycline. This fact shows the higher therapeutic potential of ethyl acetate extract of the study species. The petroleum ether extract has comparatively less activity against most of the tested pathogens. It may be attributed to the presence of respective active compounds with insufficient quantities in this crude extract (Taylor et al., 2001).

The antifungal activity of various alcoholic stem bark extracts of the study species, Acacia caesia against the ten studied fungal species is given in Table 2 . The results of the study report that the ethyl acetate extract has the highest inhibitory activity (30.77 $\mathrm{mm}$ diameter inhibitory zone) against the fungus, Mucor rouxii. The petroleum ether and methanol extracts were also found to be better with respect to inhibitory function against the two fungal species, Mucor rouxii (20.73 and $24.73 \mathrm{~mm}$ diameter inhibitory zone respectively) and Alternaria alternata (15.77 and $18.67 \mathrm{~mm}$ diameter inhibitory zone respectively). 
Table 1. Antibacterial activity of certain alcoholic stem bark extracts of the species, Acacia caesia.

\begin{tabular}{|c|c|c|c|c|c|c|c|c|c|c|}
\hline \multirow{3}{*}{$\begin{array}{c}\text { Plant } \\
\text { extract }\end{array}$} & \multicolumn{10}{|c|}{ Diameter of zone inhibition (mm) } \\
\hline & \multirow[b]{2}{*}{$\begin{array}{l}\text { Bacillus } \\
\text { subtilis }\end{array}$} & \multicolumn{3}{|c|}{ Gram positive bacteria } & \multicolumn{6}{|c|}{ Gram negative bacteria } \\
\hline & & $\begin{array}{c}B . \\
\text { thuringiensis }\end{array}$ & $\begin{array}{c}\text { Micrococcu } \\
\text { s sp. }\end{array}$ & $\begin{array}{c}\text { Lactobacillus } \\
\text { sp. }\end{array}$ & $\begin{array}{c}\text { Klebsiella } \\
\text { pneumoniae }\end{array}$ & $\begin{array}{c}\text { Escherichia } \\
\text { coli }\end{array}$ & $\begin{array}{c}\text { Pseudomonas } \\
\text { stutzeri }\end{array}$ & $\begin{array}{c}P . \\
\text { aeruginosa } \\
\end{array}$ & $\begin{array}{c}\text { Serratia } \\
\text { sp. }\end{array}$ & $\begin{array}{c}\text { Moraxetta } \\
\text { sp. }\end{array}$ \\
\hline Standard * & $\begin{array}{l}24.77 \\
\pm 0.20\end{array}$ & $\begin{array}{r}30.76 \\
\pm 0.56\end{array}$ & $\begin{array}{l}22.63 \\
\pm 0.57\end{array}$ & $\begin{array}{l}25.27 \\
\pm 0.64\end{array}$ & $\begin{array}{r}12.33 \\
\pm 0.42\end{array}$ & $\begin{array}{r}18.53 \\
\pm 0.61\end{array}$ & $\begin{array}{l}12.97 \\
\pm 0.25\end{array}$ & $\begin{array}{l}28.83 \\
\pm 0.67\end{array}$ & $\begin{array}{l}32.63 \\
\pm 0.56\end{array}$ & $\begin{array}{l}25.36 \\
\pm 0.82\end{array}$ \\
\hline $\begin{array}{l}\text { Petroleum } \\
\text { ether }\end{array}$ & $\begin{array}{l}12.87 \\
\pm 0.15\end{array}$ & $\begin{array}{r}11.16 \\
\pm 0.57\end{array}$ & - & - & $\begin{array}{r}9.16 \\
\pm 0.37\end{array}$ & - & $\begin{array}{c}8.93 \\
\pm 0.40\end{array}$ & - & - & $\begin{array}{r}6.97 \\
\pm 0.25\end{array}$ \\
\hline $\begin{array}{l}\text { Ethyl } \\
\text { acetate }\end{array}$ & $\begin{array}{r}14.13 \\
\pm 0.61\end{array}$ & $\begin{array}{r}12.13 \\
\pm 0.61\end{array}$ & $\begin{array}{r}11.73 \\
\pm 0.56\end{array}$ & $\begin{array}{c}8.77 \pm \\
0.59\end{array}$ & $\begin{array}{r}17.23 \\
\pm 0.58\end{array}$ & $\begin{array}{l}12.16 \\
\pm 0.66\end{array}$ & $\begin{array}{l}16.93 \\
\pm 0.40\end{array}$ & $\begin{array}{r}12.87 \\
\pm 0.85\end{array}$ & $\begin{array}{r}12.67 \\
\pm 0.36\end{array}$ & $\begin{array}{r}10.03 \\
\pm 0.45\end{array}$ \\
\hline Methanol & $\begin{array}{l}11.16 \\
\pm 0.47\end{array}$ & $\begin{array}{l}16.63 \\
\pm 0.60\end{array}$ & $\begin{array}{c}8.77 \\
\pm 0.56\end{array}$ & $\begin{array}{c}8.77 \\
\pm 0.32\end{array}$ & $\begin{array}{r}10.73 \\
\pm 0.75\end{array}$ & $\begin{array}{r}8.06 \\
\pm 0.30\end{array}$ & - & $\begin{array}{l}14.13 \\
\pm 0.61\end{array}$ & $\begin{array}{c}7.93 \\
\pm 0.31\end{array}$ & $\begin{array}{l}13.16 \\
\pm 0.47\end{array}$ \\
\hline
\end{tabular}

*Tetracycline

Table 2. Antifungal activity of certain alcoholic stem bark extracts of the species, Acacia caesia.

\begin{tabular}{|c|c|c|c|c|c|c|c|c|c|c|}
\hline \multirow{2}{*}{$\begin{array}{l}\text { Plant } \\
\text { extract }\end{array}$} & \multicolumn{10}{|c|}{ Diameter of zone inhibition (mm) } \\
\hline & $\begin{array}{c}\text { Aspergillus } \\
\text { niger }\end{array}$ & $\begin{array}{c}\text { A. } \\
\text { flavus }\end{array}$ & $\begin{array}{c}\text { A. } \\
\text { baumanii }\end{array}$ & $\begin{array}{r}\begin{array}{r}\text { Fusarium } \\
\text { oxysporum }\end{array} \\
\end{array}$ & $\begin{array}{c}F . \\
\text { solani } \\
\end{array}$ & $\begin{array}{l}\text { Mucor } \\
\text { rouxii }\end{array}$ & $\begin{array}{r}\text { Alternaria } \\
\text { alternata }\end{array}$ & $\begin{array}{l}\text { Candida } \\
\text { albicans }\end{array}$ & $\begin{array}{c}\text { Cladosporium } \\
\text { sp. }\end{array}$ & $\begin{array}{l}\text { Rhizopus } \\
\text { sp. } \\
\end{array}$ \\
\hline Standard * & $\begin{array}{l}27.67 \\
\pm 0.48\end{array}$ & $\begin{array}{r}28.17 \\
\pm 0.67\end{array}$ & $\begin{array}{r}26.73 \\
\pm 0.67\end{array}$ & $\begin{array}{l}30.73 \\
\pm 0.67\end{array}$ & $\begin{array}{r}23.73 \\
\pm 0.67\end{array}$ & $\begin{array}{l}25.73 \\
\pm 0.67\end{array}$ & $\begin{array}{l}27.67 \\
\pm 0.61\end{array}$ & $\begin{array}{r}10.73 \\
\pm 0.67\end{array}$ & $\begin{array}{r}15.77 \\
\pm 0.75\end{array}$ & $\begin{array}{r}40.83 \\
\pm 0.85\end{array}$ \\
\hline $\begin{array}{l}\text { Petroleum } \\
\text { ether }\end{array}$ & - & - & $\begin{array}{c}8.73 \\
\pm 0.66\end{array}$ & - & $\begin{array}{c}9.73 \\
\pm 0.70\end{array}$ & $\begin{array}{l}20.73 \\
\pm 0.67\end{array}$ & $\begin{array}{r}15.77 \\
\pm 0.75\end{array}$ & - & - & $\begin{array}{l}10.77 \\
\pm 0.75\end{array}$ \\
\hline $\begin{array}{l}\text { Ethyl } \\
\text { acetate }\end{array}$ & $\begin{array}{l}10.63 \\
\pm 0.53\end{array}$ & $\begin{array}{r}12.77 \\
\pm 0.71\end{array}$ & $\begin{array}{r}10.77 \\
\pm 0.71\end{array}$ & $\begin{array}{l}12.67 \\
\pm 0.59\end{array}$ & $\begin{array}{r}12.77 \\
\pm 0.75\end{array}$ & $\begin{array}{l}30.77 \\
\pm 0.71\end{array}$ & $\begin{array}{l}17.73 \\
\pm 0.70\end{array}$ & $\begin{array}{r}7.67 \\
\pm 0.59\end{array}$ & $\begin{array}{c}8.67 \\
\pm 0.65\end{array}$ & $\begin{array}{l}14.77 \\
\pm 0.71\end{array}$ \\
\hline Methanol & $\begin{array}{r}7.73 \\
\pm 0.54\end{array}$ & $\begin{array}{r}10.73 \\
\pm 0.70\end{array}$ & $\begin{array}{r}11.63 \\
\pm 0.65\end{array}$ & $\begin{array}{c}8.17 \\
\pm 0.38\end{array}$ & $\begin{array}{r}10.76 \\
\pm 0.71\end{array}$ & $\begin{array}{l}24.73 \\
\pm 0.67\end{array}$ & $\begin{array}{l}18.67 \\
\pm 0.65\end{array}$ & $\begin{array}{r}13.77 \\
\pm 0.75\end{array}$ & $\begin{array}{c}8.03 \\
\pm 0.91\end{array}$ & - \\
\hline
\end{tabular}

*Tetracycline 
This fact indicats the existence of strong antifungal activity of stem bark part of the study species, A. caesia and hence its effective healing property against the infectious diseases. The variation in antifungal activity across the extracts studied may be due to the polarity of the solvents used. Significantly higher inhibitory activity of ethyl acetate extract is nearly to the commercially available antibiotic tetracycline against the fungus, Mucor rouxii observed shows the superior healingness of stem bark part of $A$. caesia. Proper isolation and purification of active compounds by using ethyl acetate solvent would ensure the therapeutic value of this folklore medicinal plant when it will be used commercially.

The overall study on antimicrobial activity reports that the study species contains adequate variety of active compounds to reduce or check the growth of microbial colonies. It confirms the therapeutic value and hence the traditional usage of the stem part of the study species, A. caesia against various ailments. Further, the alcoholic extracts of stem part of this plant in general and ethyl acetate and methanol extracts in particular are suggested for the therapy of infectious diseases caused by pathogens and further studies are recommended to purify the active compounds for the formulation of new drugs, while go for commercialization.

\section{ACKNOWLEDGEMENT}

The authors are gratefully acknowledging the authorities of Tamil Nadu State Council for Science and Technology, Chennai for their financial assistance to carryout the work.

\section{REFERENCES}

Ahmed, I., Z. Mehmood and F. Mohammad, (1998). Screening of some Indian medicinal plants for their antimicrobial properties. J. Ethanophamacol. 62: 183-193.

Bauer, R.W., M.D.K. Kirby, J.C. Sherris and M. Turek, (1966). Antibiotic susceptibility testing by standard single disc diffusion method. Am. J. Clin. Pathol. 45: 493-496.
Iris, C.Z., V. Milena, M. Massimo, D. Luca and I.I. Maria, (2007). Evaluation of genotoxic and antigenotoxic effects of hydroalcoholic extracts of Zuccagnia punctata. J. Ethno pharmacol. 1: 16.

Krishnamurthy, T. (1993). Minor Forest Products of India Oxford \& IBH Publishing Co. Ltd. New Delhi.

Lee, T.H., F. Qiu, G.R. Walle and C.H. Chou, (2000). Three new flavanol galloyglycosides from leaves of Acacia confuse. J. Nat. Prod. 10: 125.

Readel, K., D. Seigier, K. Hwang, J. Keesy and S. Sellheimer, (2001). Tannins from mimosid legumes of Texas and Mexico. Econ. Bot. 55(2): 212-222.

Sathishkumar, P., S. Paulsamy, A.M. Anandakumar and P.Senthilkumar, (2009). Effect of habitat variation on the content of certain secondary metabolites of medicinal importance in the leaves of the plant, Acacia caesia Wild. J. Adv. Pl. Sci. 22(11): 451-453.

Seo, Y., J. Hoch, M. Abdel-Kader, S. Malone, I. Derveld, H. Adams, M.C.M. Werkhoven, J.H. Wisse, S.W. Mamber, J.M. Dlton and D.G.I. Kingston, (2002). Bioactive saponins from Acacia tenuifolia from the Suriname rainforest. J. Nat. Pro. 65: 170.

Tambekar, D.H. and B.S. Khante, (2010). Evaluation of antibacterial properties of ethnomedicinal herbs used by Korkus in Melghat of India against Enteric pathogens. Int. J. Pharm. Bio Sci.V1 (1) (http: //www.ijpbs.net).

Taylor, J.L., S.T. Rabe, L.J. McGraw, A.K. Jager and J. van Staden, (2001). Towards the Scientific Validation of traditional medicinal plants, $\mathrm{Pl}$. Growth Regul. 34: 23-37.

Thammanna and R.K. Narayana, (1990). Medicinal Plants of Tirumala. $1^{\text {st }}$ ed. Department of Gardens, Tirumala Tirupahti Devasthanams, Tirupathi.

Zaika, L.I., (1975). Spices and Herbs, their antimicrobial activity and its determination. J. Food Saf. 9: 97-118. 